\title{
Investigation of the physicochemical, nutritional properties and antioxidant activities of commercial and traditional pomegranate molasses samples
}

\section{Sema Özmert Ergin $®$}

Cite this article as:

Özmert Ergin, S. (2020). Investigation of the physicochemical, nutritional properties and antioxidant activities of commercial and traditional pomegranate molasses samples. Food and Health, 6(3), 177-185. https://doi.org/10.3153/FH20019

Mehmet Akif Ersoy University, Faculty of Health Sciences, Department of Nutrition and Dietetics, Burdur, Turkey

ORCID IDs of the authors: S.Ö.E. 0000-0001-7742-8185

Submitted: 17.10 .2019

Revision requested: 25.03 .2020

Last revision received: 30.03 .2020

Accepted: 21.04 .2020

Published online: 11.06 .2020

Correspondence: Sema ÖZMERT ERGINN

E-mail: sozmert@mehmetakif.edu.tr

\begin{abstract}
Pomegranate molasse is a pomegranate product which has become widespread in recent years and can be added to some foods with its unique taste and aroma. In this study, three commercial sold in the market and three pomegranate molasses made by traditional method taken from Burdur (Turkey) public market were investigated. The $\mathrm{pH}$, water soluble dry matter results of the samples were found to comply with the standards. Viscosity values range from 191.35 to $13000 \mathrm{mPa}$. According to the color analysis, it was detected that the color of the traditional pomegranate molasses was darker than the commercial ones. The phenolic content of samples varies between 10.40$931.56 \mathrm{mg} \mathrm{GAE} / \mathrm{L}$. The highest quantity of antioxidant substance was found in the commercial C2 sample. Total aerobic mesophilic bacteria count was carried out to evaluate the hygienic quality of pomegranate molasses samples. It was seen that the most bacteria number was at $\mathrm{C} 1$ commercial pomegranate molasse. It was concluded that it would be beneficial to elaborate pomegranate molasse standards and in traditional production, more healthy and reliable products can be obtained with the informations.
\end{abstract}

Keywords: Antioxidant activity, Hygienic quality, Nutrition, Pomegranate molasse

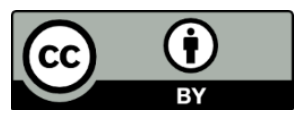

(C) Copyright 2020 by ScientificWebJournals Available online at

http://jfhs.scientificwebjournals.com 


\section{Introduction}

Pomegranate is a fruit of the Punicaceae family, Punica granatum Linnaeus species, suitable for growing in temperate climates. Pomegranate, an important commercial product in Asia, North Africa, Mediterranean and Middle East countries, is mostly grown in the Mediterranean Region in Turkey (Sarkosh et al., 2006). Therapeutic effects of pomegranate fruit have been known for centuries. Anthocyanins, flavonoids, hydrolyzable tannins, organic acids, vitamins, minerals in pomegranate provide its antioxidant and antimicrobial effects (Vardin and Fenercioğlu, 2003; Lansky and Newman, 2007). Pomegranate fruit has preventive effect on diabetes, cancer and cardiovascular diseases. In addition, it is useful in the treatment of diseases such as ulcer, diarrhea, dysentery, hemorrhoids and food poisoning (Viuda-Martos et al., 2010; Prashanth et al., 2001). The pomegranate products made from pomegranate (pomegranate juice, pomegranate juice concentrate, pomegranate vinegar, pomegranate wine, pomegranate molasse) are also beneficial for human health.

Pomegranate molasse is a pomegranate product used in salads, as sweetener and flavoring sauce in some meals (raw meatballs, k1sır, dolma and etc.) (Maskan, 2009). In parallel to widespread pomegranate production in Turkey, pomegranate molasse is among the products that have increased production and consumption in recent years. According to the Turkish Standarts (Anonymous, 2001) pomegranate molasse is defined as 'it is a sour food product that produced by pressing pomegranate fruit, clarifying pomegranate juice and evaporating open or under vacuum technique and used to flavoring some foods'.

Pomegranate molasse can be obtained commercially or traditionally. The traditional production stages of pomegranate molasse are; washing pomegranate, shredding, pressing, boiling pomegranate juice, cooling, filtering and bottling (Karabıyıklı and Kışla, 2012). No sugar or additive is added in the production by traditional method. In commercial production, there are pasteurization of pomegranate juice, enzyme addition, clarification, filtration, evaporation stages. In these stages, glucose/fructose syrup, citric acid, antioxidant agents, colorant and preservatives can be added to the product (Karaca, 2011; Kışla and Karabıyıklı, 2013). Pomegranate molasse is a high nutritional value product and has a strong antioxidant effect. In this regard, it has the function of preventing diabetes, cancer and cardiovascular diseases (Inceday1 et al., 2010; El-Darra et al., 2017). In addition, pomegranate molasse is a product that rich in terms of phenolic compounds and minerals as potassium, magnesium, calcium, zinc (Fadavi et al., 2005).
In this study, some physicochemical properties such as $\mathrm{pH}$, dry matter content, viscosity, color and phenolic content, antioxidant capacity and hygienic quality of the pomegranate molasses samples produced by commercial and traditional methods were investigated.

\section{Materials and Methods}

\section{Supply of Pomegranate Molasses Samples}

In this study, a total of six pomegranate molasses samples were used for analysis, three of which were produced by commercial method and three of which were produced by traditional method. The commercial pomegranate molasses samples $(\mathrm{C} 1, \mathrm{C} 2, \mathrm{C} 3)$ were purchased from a local supermarket in Burdur (Turkey). And traditional pomegranate molasses samples (T1, T2, T3) were purchased from different producers in the public market in Burdur. T1 is produced in Kahramanmaraş, T2 in Antalya and T3 in Burdur. All of the samples used in the study were produced in 2017. The samples were stored at $4{ }^{\circ} \mathrm{C}$ during the analysis, commercial ones at glass bottles, and traditional ones at plastic bottles.

\section{Physicochemical Analysis}

The $\mathrm{pH}$ values of the pomegranate molasses samples were determined by the digital $\mathrm{pH}$ meter (Mettler Toledo S20KKit). The dry matter quantities of the samples were determined according to TS 4890 refractometer method (Anonymous, 1986). The Brookfield RVDV-11 + PX was used to determine the viscosity values and the results were given in milipascal. $L^{*}$ brightness, $a^{*}$ redness and $b^{*}$ yellowness values of commercial and traditional pomegranate molasses samples were determined with color measurement device (Konika Minolta Chroma Meter Cr-400/410). The L* value is between 0-100 (black-white) and refers to brightness. The positive $a^{*}$ value represents red color, the positive $b^{*}$ value is yellow color; negative $a^{*}$ represents green color and negative $\mathrm{b}^{*}$ is blue color (Legua et al., 2016).

\section{Determination of Total Phenolic Content}

The total phenolic contents of pomegranate molasses samples were detected by Folin-Ciocalteau method suggested by Singleton et al. (1965). Firstly, extracts were prepared for phenolic content analysis. For this, 2 grams of the samples were taken and $10 \mathrm{~mL}$ of $96 \%$ ethanol was added on it. It was mixed with the homogenizer for two minutes and kept in a water bath at $45{ }^{\circ} \mathrm{C}$ overnight. After this time, it was centrifuged at $4000 \mathrm{rpm}$ for 5 minutes. Then dried at $45{ }^{\circ} \mathrm{C}$ in the evaporator. The prepared extracts were dissolved in $1 \mathrm{~mL}$ of methanol and used in the analysis. $40 \mu \mathrm{L}$ of extract was taken into the test tube containing $2.4 \mathrm{~mL}$ of distilled water. $200 \mu \mathrm{l}$ of Folin-Ciocalteau reagent and $600 \mu \mathrm{L}$ sodium carbonate 
were added on it. To this, $760 \mu \mathrm{L}$ distile water is added and vortexed. After standing at room temperature for 2 hours, the absorbance was read at $765 \mathrm{~nm}$ spectrophotometer. The same processes were applied to the gallic acid solutions prepared in different concentrations for the calibration curve. The absorbance of the extract solution was read from the drawn gallic acid calibration curve and the total phenolic content was calculated as the gallic acid equivalent (mg GAE/L).

\section{Determination of Antioxidant Activity}

DPPH (2,2-diphenyl-1-picrylhydrazyl) radical scavenging activity method was used to determine the antioxidant activity of the samples. Accordingly, 2 grams of the sample were homogenized with $10 \mathrm{ml}$ of $96 \%$ ethanol. $1 \mathrm{~mL}$ of this mixture was taken and $1 \mathrm{~mL}$ of DPPH solution was added on it. After waiting for 30 minutes in a dark environment, the absorbance was measured at $517 \mathrm{~nm}$ (Sahu et al., 2013).

\section{Determination of Total Aerobic Mesophilic Bacteria}

Total aerobic mesophilic bacteria count was performed as the hygienic quality parameter in the pomegranate molasses samples. For this, rapid microbiological analyzer was used (Biomerux, Tempo). The results were given as $\mathrm{cfu} / \mathrm{mL}$ (colony forming unit) (Anonymous, 2009).

\section{Statistical Analysis}

All analyzes except for color measurement and total aerobic mesophilic bacteria were performed in three replicates. The results were analyzed with SPSS 16.0 statistical program and shown as mean \pm standard deviation. Spearman correlation test was used between the phenolic content and antioxidant content of samples.

\section{Results and Discussion}

\section{Physicochemical Analysis}

In order to determine the physicochemical characterization of pomegranate molasses samples; $\mathrm{pH}$ values, dry matter quantities, viscosity values and color measurement values were investigated. The results of the physicochemical analysis of pomegranate molasses samples are shown in Table 1.

As the seen in the table, the $\mathrm{pH}$ values of pomegranate molasses samples have changed between 1.79 and 2.77. Inceday1 et al., (2010) reported that the $\mathrm{pH}$ values of seven different commercial pomegranate molasses samples were between
0.87 and 1.98. And in the study of Kaya and Sozer (2005), this value determined as 2.05 . The $\mathrm{pH}$ value may vary depending on the type of pomegranate fruit, sugar content, amount of organic acid, region where it grows. In addition, different applications in the production of pomegranate molasse effect the $\mathrm{pH}$ value, hence the sourness-sweetness status (Melgarejo and Artes, 2000; Tehranifar et al., 2000).

According to Turkish Standart of pomegranate molasses, it is stated that the dry matter quantity of pomegranate molasse as at least 68\% (Anonymous, 2001) (Table 2). All of the samples used in the study comply with the standard. The sample with the lowest quantity of dry matter is $\mathrm{C} 3(69.90 \%)$ and the highest is C1 $(86.23 \%)$. Yilmaz et al. (2007) reported that the moisture content of commercial pomegranate molasses samples was $24.4 \%$ on average in their study. Therefore, the dry matter quantities of these samples is around $75.6 \%$.

The resistance of liquid foods against fluidity is viscosity. Foods with high viscosity value are more dense and flow rates are slow. The viscosity values of the pomegranate molasses samples in the study vary between 191.35 and $13000 \mathrm{mPa}$. The sample with the highest viscosity is $\mathrm{C} 1(13000 \mathrm{mPa})$ and the lowest one is C3 $(191.35 \mathrm{mPa})$. These results are similar to the results of dry matter quantity. Among the samples, only $\mathrm{C} 1$ contains fructose syrup. It is thought that high viscosity and dry matter content of $\mathrm{C} 1$ can be caused by fructose syrup. The average viscosity values are calculated as $5344.11 \pm 6761$ in commercial pomegranate molasses samples, $2593.48 \pm 1071$ in traditional pomegranate molasses samples. Incedayi et al. (2010) found the viscosity values of pomegranate molasses samples are between $200-1800 \mathrm{mPa}$. In a study using commercial pomegranate molasses, it was reported that the viscosity values were between $176-2900 \mathrm{mPa}$ (Akpinar Bayızit et al., 2016). In natural pomegranate molasses, low dense and high dense consistency are not desired. Low dence molasse can not provide the desired aroma, also nutritious value is low. And high dense pomegranate molasse can not show homogenous distribution when used as sauce. The results of the study confirm that viscosity is an important parameter in the production of pomegranate molasse. It is expected that the appropriate viscosity values will be included in the pomegranate molasse standards with studies to do about it. 
Table 1. Physicochemical analysis results of pomegranate molasses samples

\begin{tabular}{ccccccc}
\hline Sample & $\mathrm{pH}$ & $\begin{array}{c}\text { Dry matter quantity } \\
(\%)\end{array}$ & Viscosity $(\mathrm{mPa})$ & \multicolumn{3}{c}{ Color values } \\
& & & & $\mathrm{L}^{*}$ & $\mathrm{a}^{*}$ & $\mathrm{~b}^{*}$ \\
\hline $\mathrm{C} 1$ & $1.91 \pm 0.00$ & $86.23 \pm 0.15$ & $13000.00 \pm 875.00$ & 22.09 & 0.14 & 0.37 \\
$\mathrm{C} 2$ & $1.79 \pm 0.00$ & $82.70 \pm 0.20$ & $2841.66 \pm 14.43$ & 21.17 & 1.19 & 0.42 \\
$\mathrm{C} 3$ & $2.77 \pm 0.01$ & $69.90 \pm 0.26$ & $191.35 \pm 1.06$ & 20.85 & 0.34 & 0.36 \\
$\mathrm{~T} 1$ & $2.13 \pm 0.00$ & $84.13 \pm 0.20$ & $1683.33 \pm 7.21$ & 20.71 & 0.19 & 0.40 \\
$\mathrm{~T} 2$ & $1.89 \pm 0.00$ & $83.30 \pm 0.20$ & $3773.80 \pm 20.61$ & 20.67 & 0.24 & 0.19 \\
$\mathrm{~T} 3$ & $1.90 \pm 0.01$ & $81.30 \pm 0.36$ & $2323.33 \pm 55.48$ & 19.73 & 0.16 & 0.41 \\
\hline
\end{tabular}

Data are reported as mean values \pm SD of three measurements

Table 2. General composition of the pomegranate molasses (Anonymous, 2001)

\begin{tabular}{ll}
\hline Components & Amount \\
\hline Water soluble dry matter, \%, minimum & 68.0 \\
Titration acidity (as citric acid), \%, minimum & 7.5 \\
$\mathrm{pH}$ & 3.0 \\
$\mathrm{HMF}, \mathrm{mg} / \mathrm{kg}$, maximum & 50 \\
Saccharose, preservative agent, coloring agent & Not allowed \\
\hline
\end{tabular}

The results of color analysis of commercial and traditional pomegranate molasses samples are shown in Table 1 . L* refers to brightness (lightness-darkness), $a *$ redness and $b *$ yellowness. The $\mathrm{L}^{*}$ brightness values of the samples are in the range of 19.73-22.09. Relation to the $\mathrm{L}^{*}$ value, ranging from $0-100$, values close to 0 indicates darkness and values close to 100 indicates lightness. According to this, the darkest sample is T3 and the lightest sample is C1. Orak (2009) found the $\mathrm{L}^{*}$ values of the pomegranate juice and pomegranate molasse obtained from this as 10.24, 4.92 respectively. It is stated in the study that the color is darkened as a result of heat treatment. In addition, anthocyanins which give red color to the fruit are decomposed as a result of the heat treatment and a darker color emerges with non-enzymatic browning reactions (Cemeroglu and Artık, 1990). a* shows low values with decreasing in red color. In our study, the highest a* value is seen in C2 (1.19). In a study $L^{*}, a^{*}$ and $b^{*}$ values of pomegranate molasses samples were found as $1.88,0.57$ and -0.31 respectively. It is reported that these values represent darkness, light red and blue color (Y1lmaz et al., 2007). Maskan (2006) stated that all color parameters $\left(\mathrm{L}^{*}, \mathrm{a}^{*}, \mathrm{~b}^{*}\right)$ have decreased over time as a result of the heat treatment of pomegranate juice. In the study of Orak (2009), a* value decreased from 12.33 to 1.82 and the value of $\mathrm{b}^{*}$ decreased from 2.38 to 1.60 in the process of product pomegranate molasse from juice. $\mathrm{L}^{*}, \mathrm{a}^{*}, \mathrm{~b}^{*}$ values of grape molasses were measured as 18.87 , 4.99, -1.61 (Ertaş and Coklar, 2008). According to these results, it can be said that grape molasses are darker than the pomegranate molasses, the red color is more and the blue color is more dominant.

\section{Total Phenolic Content}

The phenolic substances are compounds play an important role in human health and found naturally in fruits and vegetables (especially in red color) (Tzulker et al., 2007). Phenolic contents of pomegranate juice include phenolic acids, hydrolysable tannins and anthocyanins. Gallic acid, elagic acid, chlorogenic acid, coumaric acid, $\alpha$-punicalagin, $\beta$-punicalagin, delfinidine-3,5-diglycoside, cyanidine-3,5-diglycoside, pelargonidine-3,5-diglycoside, cyanidin-3-glycoside, delfinidin-3-glycoside, pelargonidin-3-glycoside are some of them (Poyrazoglu et al., 2002; Alighourchi et al., 2008). Table 3 shows the total phenolic content of commercial and traditional pomegranate molasses samples and the corresponding calibration curve in Figure 1. Accordingly, the sample with the highest phenolic content is C3 (931.56 mg GAE/L). $\mathrm{C} 3$ is in the second row with regard to antioxidant substance. Inceday1 et al (2010) reported that the total amount of polyphenol in commercial pomegranate molasses samples ranged between 551.61 and $9695.17 \mathrm{mg} \mathrm{GAE} / \mathrm{kg}$. It is expected that the content of phenolic substance will be increased in pomegranate molasse which is a concentrate product. In a study, the total phenolic content of pomegranate juice and pomegranate molasse obtained from this were compared. Total phenolic content of pomegranate molasse was found to be three times higher than the pomegranate juice (Orak, 2009). In our study, the average phenolic content of commercial pomegranate molasses samples was found to be higher $(490.22 \pm 278)$ than the traditional pomegranate molasses samples $(24.11 \pm 4.06)$. 
Figure 1. Total phenolic content analysis calibration curve

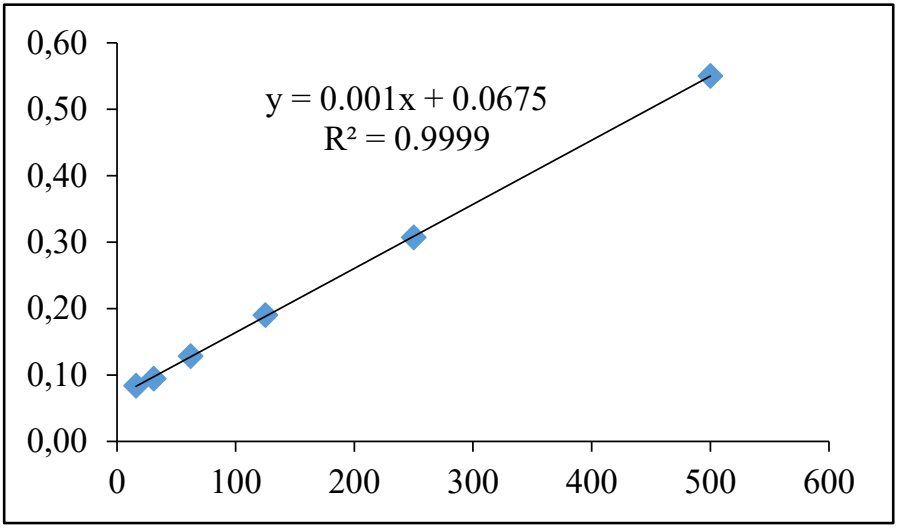

Table 3. Total phenolic content of pomagranate molasses samples

\begin{tabular}{ll}
\hline Sample & Total phenolic content $(\mathrm{mg} \mathrm{GAE} / \mathrm{L})$ \\
\hline C1 & $528.71 \pm 21.87$ \\
$\mathrm{C} 2$ & $10.40 \pm 9.45$ \\
$\mathrm{C} 3$ & $931.56 \pm 14.43$ \\
T1 & $28.63 \pm 8.89$ \\
T2 & $22.98 \pm 11.78$ \\
T3 & $20.74 \pm 26.23$ \\
\hline Data are reported as mean values \pm SD of three measurements
\end{tabular}

\section{Total Antioxidant Content}

It is also known that foods with high phenolic content are high in antioxidant activity. The consumption of foods with antioxidant content is important in protecting the cells by preventing oxidation reactions in the body (Karadeniz et al., 2005). Pomegranate fruit is one of the foods with high antioxidant effect. In the study, the antioxidant content of pomegranate molasses are between 0.68-735.28 $\mu \mathrm{mol} \mathrm{TE} / \mathrm{g}$ and $\mathrm{C} 2>\mathrm{C} 3>\mathrm{T} 1>\mathrm{T} 3>\mathrm{T} 2>\mathrm{C} 1$. The average quantity of antioxidant substances in commercial pomegranate molasses samples is $356.40 \pm 367$ and $1.64 \pm 1.60$ in traditional pomegranate molasses samples (Table 4). The calibration curve for the analysis of antioxidant capacity is shown in Figure 2. In order to reduce costs in the production of pomegranate molasse, there may be adulterations. Fruit juice, colorant, thickener, antioxidant, glucose-fructose syrup can be added (El Darra et al., 2017). This makes it difficult to compare the antioxidant activity of commercial and traditional pomegranate molasses samples. In addition, the fact that they are not indicated on the label can pose a risk to consumers (Boggia et al., 2013). In a study in which antioxidant capacities of commercial pomegranate molasses were measured by DPPH method, the lowest value was 140.22 ; the highest value is $471.85 \mu \mathrm{mol}$
TE/g (Akpınar Bayızit et al., 2016). According to this, the antioxidant capacity of $\mathrm{C} 1$ sample in our study is very low. In a study using the same method, the quantity of antioxidant substance in pomegranate juice ranged between 8.98-15.47 $\mu \mathrm{mol}$ TE/g (Kaur et al., 2014). Oztan (2006) was found the antioxidant capacities of freshly squeezed pomegranate juice, commercial pomegranate juice and commercial pomegranate molasse samples as $52.12,46.24,54.8 \mu \mathrm{mol} \mathrm{TE} / \mathrm{g}$ respectively.

Table 4. Total antioxidant content of pomagranate molasses samples

\begin{tabular}{ll}
\hline Sample & Total antioxidant content $(\mu \mathrm{molTE} / \mathrm{g})$ \\
\hline C1 & $0.68 \pm 0.14$ \\
C2 & $735.28 \pm 32.8$ \\
C3 & $333.24 \pm 29.58$ \\
T1 & $3.49 \pm 0.55$ \\
T2 & $0.70 \pm 0.07$ \\
T3 & $0.73 \pm 0.08$ \\
\hline
\end{tabular}

Data are reported as mean values \pm SD of three measurements

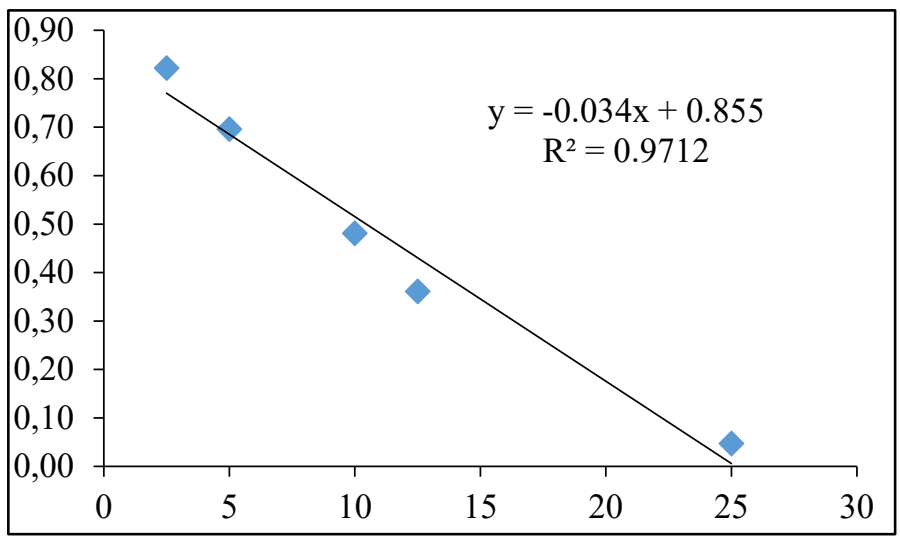

Figure 2. Total antioxidant content analysis calibration curve

\section{Correlation Between Phenolic and Antioxidant Contents}

Spearman test was used to determine whether there is a correlation between the phenolic and antioxidant contents of the samples. It is expected that the sample with high phenolic content to have high antioxidant activity. According to Table 5 , there was no significant correlation between phenolic content and antioxidant activity ( $\mathrm{p}>0.05)$. This may be due to the different phenolic content of different pomegranate species. In addition, various additives used in pomegranate molasses especially commercial ones, may also affect the results. 


\section{Total Aerobic Mesophilic Bacteria Count}

Figure 3 shows the total aerobic mesophilic bacteria count (TAMB) found in pomegranate molasses samples. The total aerobic mesophilic bacteria count was determined by TEMPO TVC rapid test method. The total number of live bacteria ensures the hygienic evaluation of the product. In general, foods with a total aerobic mesophilic bacteria count is at $10^{6}-10^{8} / \mathrm{g}$ are risky in terms of consumption and their hygienic qualities are low (Anonymous, 2005). Looking at the table, it is observed that all of the pomegranate molasse samples are below these values. The sample with the highest number of aerobic mesophilic bacteria is commercial $\mathrm{C} 1$ sample $\left(4.9 \times 10^{4} \mathrm{cfu} / \mathrm{mL}\right)$. It has been reported that pomegranate molasses have antimicrobial properties and are mostly due to phenolic compounds, especially hydrolyzable tannins (Gullon et al., 2016). In a study in which pomegranate molasse was used as a sauce, pomegranate molasses samples showed antimicrobial effect on foods and prevented microbial growth in foods. In this study, it is also stated that the antimicrobial effect of the pomegranate molasses samples produced by the traditional method is higher than the samples produced by commercial method (Karabiyıklı and Kışla, 2012). In a study, washing water with pomegranate molasse was used for washing some vegetables and its antimicrobial effect was investigated. As a result of this study, it was found that the levels of Listeria monocytogenes decreased 1.96-2.97 $\log \mathrm{cfu} / \mathrm{g}$ in the vegetables (Kang and Song, 2017). In another study, the traditional pomegranate molasse applied to parsley leaves and ready-to-eat salads. It was reported that the pomegranate molasse had a significant antibacterial effect against Salmonella typhimurium and enhanced the microbial safety of these foods (Faour-Klingbeil and Todd, 2018).

\section{Conclusions}

Pomegranate molasse is a pomegranate product with high nutritional value known for its flavor-enhancing effect when used in foods. The production technique of pomegranate molasse affects its nutritional value, hygienic quality, sensory properties and taste. In this study, pomegranate molasses samples produced by commercial and traditional methods were investigated. It was observed that all samples comply with the standards in terms of $\mathrm{pH}$ and dry matter quantity. The commercial $\mathrm{C} 1$ sample with the highest viscosity was determined to contain fructose syrup. The adulterations that can be done in production can interfere to a healthy comparison and evaluation. Similarly, adulterations such as colorant, thickener and antioxidant addition may also change the results. In the study, the sample with the highest phenolic content is $\mathrm{C} 3$ and the highest antioxidant content is $\mathrm{C} 2$. The hygienic quality of pomegranate molasses samples used in the study is high. Although it is thought that the hygienic quality of the samples produced by traditional method will be low, the total number of aerobic mesophilic bacteria was found to be highest in commercial $\mathrm{C} 1$ sample. Pomegranate molasse which has positive effects on human health should take place in diet more. In terms of commercial production, pomegranate molasse standards should be expanded, more detailed and adulterations should be prevented. It will be useful to include the parameters of viscosity and hygienic quality in pomegranate molasse standards. On the other hand, traditional production of pomegranate molasses should be supported. Producers should be informed about the hygienic conditions during production stages.

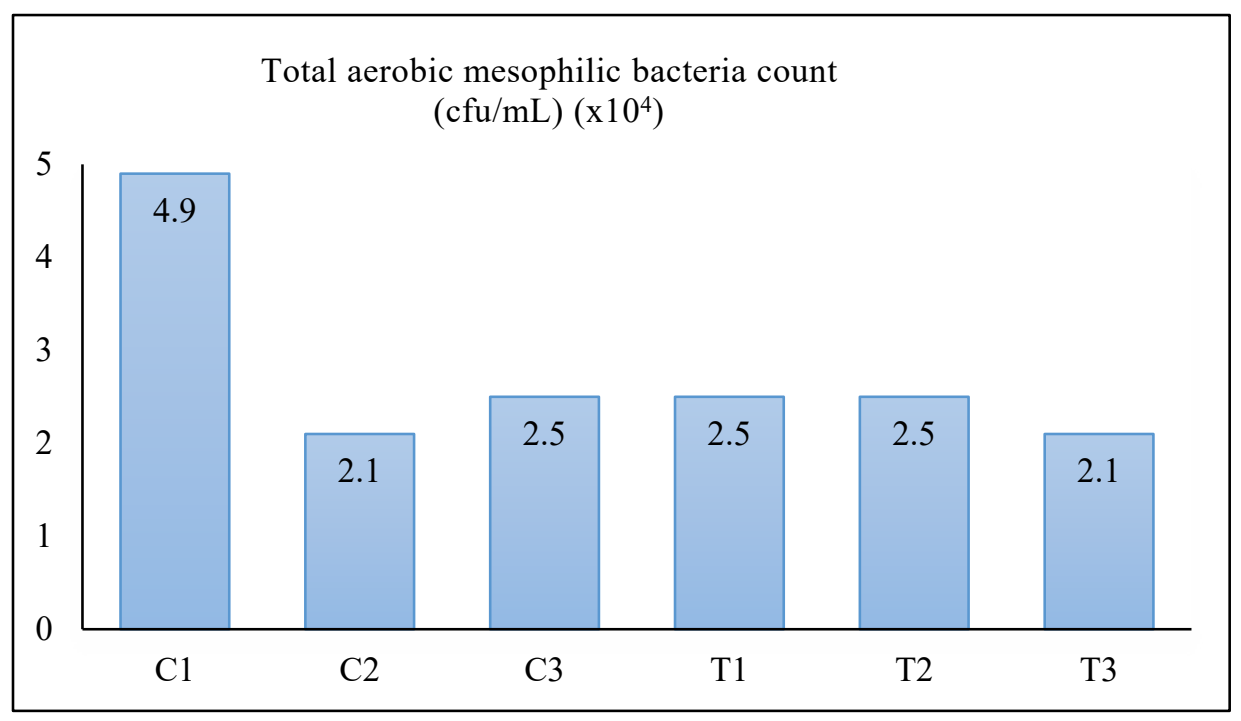

Figure 3. TAMB count of pomegranate molasses samples 
Table 5. The correlation values between total phenolic and antioxidant contents of molasses

\begin{tabular}{lllrr}
\hline & & Phenolic content & Antioxidant content \\
\hline Spearman's rho & Phenolic content & Correlation Coefficient & 1.000 & -0.257 \\
& & Sig. (2-tailed) &. & 0.623 \\
& N & 6 & 6 \\
& \multirow{2}{*}{ Antioxidant content } & Correlation Coefficient & -0.257 & 1.000 \\
& & Sig. (2-tailed) & 0.623 &. \\
& & N & 6 & 6 \\
\hline
\end{tabular}

\section{Compliance with Ethical Standard}

Conflict of interests: The authors declare that for this article they have no actual, potential or perceived the conflict of interests.

Ethics committee approval: Author declare that this study does not include any experiments with human or animal subjects.

Funding disclosure: -

Acknowledgments: -

\section{References}

Akpınar Bayızit, A., Ozcan, T., Yılmaz Ersan, L., Yıldız, E. (2016). Evaluation of antioxidant activity of pomegranate molasses by 2,2-diphenyl-1-picrylhydrazyl (DPPH) method. International Journal of Chemical Engineering and Applications, 7(1), 71-74.

https://doi.org/10.7763/IJCEA.2016.V7.545

Alighourchi, H., Barzegar, M., Abbasi, S. (2008). Anthocyanins characterization of 15 Iranian pomegranate (Punica granatum L.) varieties and their variation after cold storage and pasteurization. European Food Research and Technology, 227, 881-887.

https://doi.org/10.1007/s00217-007-0799-1

Anonymous (1986). Meyve ve Sebze Mamulleri Çözünür Katı Madde Miktarı Tayini. Refraktometrik Yöntem, TS 4890, Türk Standartları Enstitüsü, Ankara.

Anonymous (2001). Nar ekşisi standartı, TS 12720, Türk Standartları Enstitüsü, Ankara.

Anonymous (2005). Merck Gida Mikrobiyolojisi Uygulamaları. Ed: A.K. Halkman. Ankara: Başak Matbaacılık, 358 s., ISBN: 975-00373-0-8
Anonymous (2009). TEMPO TVC (total viable count) REF 80 007, Bio-merieux, Marcy-l'Etoile, France.

Boggia, R., Casolino, M. C., Hysenaj, V., Oliveri, P., Zunin, P. (2013). A screening method based on UV-visible spectroscopy and multivariate analysis to assess addition of filler juices and water to pomegranate juices. Food Chemistry, 140, 735-741.

https://doi.org/10.1016/j.foodchem.2012.11.020

Cemeroğlu, B., Artık, N. (1990). Isıl işlem ve depolama koşullarının nar antosiyaninleri üzerine etkisi. Glda, 15, 1319.

El Darra, N., Rajha, H.N., Saleh, F., Al-Oweini, R., Maroun, R. G., Louka, N. (2017). Food fraud detection in commercial pomegranate molasses syrups by UV-VIS spectroscopy, ATR-FTIR spectroscopy and HPLC methods. Food Control, 78, 132-137.

https://doi.org/10.1016/j.foodcont.2017.02.043

Ertaş, N., Çoklar, H. (2008). Farklı pekmez çeşitlerinin doğal şeker kaynağı olarak kek hamuru ve kek özelliklerine etkisi. Selçuk Üniversitesi Ziraat Fakültesi Dergisi, 22(46), 51-54.

Fadavi, A., Barzegar, M., Azizi, H. M., Bayat, M. (2005). Physicochemical composition of ten pomegranate cultivars (Punica granatum L.) grown in Iran. Food Science and Technology International, 11, 113-119.

https://doi.org/10.1177/1082013205052765

Faour-Klingbeil, D., Todd, E.C.D. (2018). The inhibitory effect of traditional pomegranate molasses on S. typhimurium growth on parsley leaves and in mixed salad vegetables. Journal of Food Safety, 38, e12469.

https://doi.org/10.1111/jfs.12469 
Gullon, B., Pinatado, M.E., Perez-Alvarez, J.A., ViudaMartos, M. (2016). Assesment of polyphenolic profile and antibacterial activity of pomegranate peel (Punica granatum) flour obtained from co-product of juice extraction. Food Control, 59, 94-98.

https://doi.org/10.1016/j.foodcont.2015.05.025

Incedayı, B., Tamer, C.E., Copur, O.U. (2010). A research on the composition of pomegranate molasses. Uludağ Üniversitesi Ziraat Fakültesi Dergisi, 24(2), 37-47.

Kang, J.H., Song, K.B. (2017). Effect of pomegranate pomace extract as a washing agent on the inactivation of Listeria monocytogenes inoculated on fresh produce. International Journal of Food Science and Technology, 52, 2295-2302. https://doi.org/10.1111/ijfs.13511

Karabıyıklı, Ş., Kışla, D. (2012). Inhibitory effect of sour pomegranate sauces on some green vegetables and kisir. International Journal of Food Microbiology, 155, 211-216.

https://doi.org/10.1016/j.ijfoodmicro.2012.02.006

Karaca, E. (2011). Nar suyu konsantresi üretiminde uygulanan bazı işlemlerin fenolik bileşenler üzerine etkisi. (Master thesis), University of Çukurova, Adana.

Karadeniz, F., Burdurlu, H.S., Koca, N., Soyer, Y. (2005). Antioxidant activity of selected fruits and vegetables grown in Turkey. Turkish Journal of Agriculture and Forestry, 29, 297-303.

Kaur, C., Pal, R.K., Kar, A., Gadı, C., Sen, S., Kumar, P., Chandra, R., Jaiswal, S., Khan, I. (2014). Characterization of antioxidants and hypoglycemic potential of pomegranate grown in India: a preliminary investigation. Journal of Food Biochemistry, 38, 397-406.

https://doi.org/10.1111/jfbc.12066

Kaya, A., Sözer, N. (2005). Rheological behaviour of sour pomegranate juice concentrates (Punica granatum L.). International Journal of Food Science and Technology, 40, 223227.

https://doi.org/10.1111/j.1365-2621.2004.00897.x
Kışla, D., Karabıyıklı, Ş. (2013). Antimicrobial effect of sour pomegranate sauce on Escherichia coli $\mathrm{O} 157: \mathrm{H} 7$ and $S$. aureus. Journal of Food Science, 78(5), 715-718.

https://doi.org/10.1111/1750-3841.12099

Lansky, E.P., Newman, R.A. (2007). Punica granatum (pomegranate) and its potential for prevention and treatment of inflammation and cancer. Journal of Ethnopharmacology, 109, 177-206.

https://doi.org/10.1016/j.jep.2006.09.006

Legua, P., Forner-Giner, M.A., Nuncio-Jauregui, N., Hernandez, F. (2016). Polyphenolic compounds, anthocyanins and antioxidant activity of nineteen pomegranate fruits: A rich source of bioactive compounds. Journal of Functional Foods, 23, 628-636.

https://doi.org/10.1016/j.jff.2016.01.043

Maskan, M. (2006). Production of pomegranate (Punica granatum L.) juice concentrate by various heating methods: colour degradation and kinetics. Journal of Food Engineering, 72, 218-224.

https://doi.org/10.1016/j.jfoodeng.2004.11.012

Melgarejo, P., Artes, F. (2000). Organic acids and sugar composition of pomegranate juice. European Food Research and Technology, 4, 30-31.

Orak, H.H. (2009). Evaluation of antioxidant activity, colour and some nutritional characteristics of pomegranate (Punica granatum L.) juice and its sour concentrate processed by conventional evaporation. International Journal of Food Sciences and Nutrition, 60(1), 1-11.

https://doi.org/10.1080/09637480701523306

Oztan, T. (2006). Mor havuç, konsantresi, şalgam suyu, nar suyu ve nar ekşisi ürünlerinde antioksidan aktivitesi tayini ve fenolik madde profilinin belirlenmesi. Master thesis, Istanbul Technical University, Istanbul.

Poyrazoğlu, E., Gökmen, V., Artık, N. (2002). Organic acids and phenolic compounds in pomegranates (Punica granatum L) grown in Turkey. Journal of Food Composition and Analysis, 15(5), 567-575.

https://doi.org/10.1016/S0889-1575(02)91071-9 
Prashanth, D., Asha, M.K., Amit, A. (2001). Antibacterial activity of Punica granatum. Fitoterapia, 72, 171-173.

https://doi.org/10.1016/S0367-326X(00)00270-7

Sahu, R.K., Kar, M., Routray, R. (2013). DPPH free radical scavenging activity of some leafy vegetables used by tribals of Odisha, India. Journal of Medicinal Plants Studies, 1(4), 21-27.

Sarkhosh, A., Zamani, Z., Fatahi, R., Ebadi, A. (2006). RAPD markers reveal polymorphism among some Iranian pomegranate (Punica granatum L.) genotypes. Scientia Horticulturae, 111, 24-29.

https://doi.org/10.1016/j.scienta.2006.07.033

Singleton, V.L., Rossi, J.A. (1965). Colorimetry of total phenolics with phosphomolybdic-phosphotungstic acid reagents. American Journal of Enology and Viticulture, 16, 144-158.

Tehranifar, A., Zarei, M., Nemati, Z., Esfandiyari, B., Vazifeshenas, M.R. (2010). Investigation of physico-chemical properties and antioxidant activity of twenty Iranian pomegranate (Punica granatum L.) cultivars. Scientia Horticulturae, 126, 180-185.

https://doi.org/10.1016/j.scienta.2010.07.001
Tzulker, R., Glazer, I., Bar-IIan, I., Holland, D., Aviram, M., Amir, R. (2007). Antioxidant activity, polyphenol content and related compounds in different fruit juices and homogenates prepared from 29 different pomegranate accessions. Journal of Agriculture and Food Chemistry, 55, 95599570 .

https://doi.org/10.1021/jf071413n

Vardin, H., Fenercioglu, H. (2003). Study on the development of pomegranate juice processing technology: Clarification of pomegranate juice. Nahrung/Food, 47, 300-303.

https://doi.org/10.1002/food.200390070

Viuda-Martos, M., Fernandez-Lopez, J., Perez-Alvarez, J.A. (2010). Pomegranate and its many functional components as related to human health: A review. Comprehensive Reviews in Food Science and Food Safety, 9, 635-654. https://doi.org/10.1111/j.1541-4337.2010.00131.x

Yılmaz, Y., Celik, I., Isık, F. (2007). Mineral composition and total phenolic content of pomegranate molasses. Journal of Food, Agriculture and Environment, 5(3-4), 102-104. 